\title{
Geology and evaluation of hydrocarbon prospects of Tethyan sediments in Spiti Valley, Spiti and Zanskar, Himanchal Pradesh
}

\author{
J agmohan Singh*, S Mahanti and Kamla Singh \\ Present address: RGL, WO, ONGC, Baroda-390007, Gujrat, INDIA \\ * To whom correspondence should beaddressed. E-mail: jagmohansingh@hotmail.com
}

Keshava Deva Malaviya Institute of Petroleum Exploration, Oil and Natural Gas Corporation Limited, Dehra Dun-248001, INDIA

The Tethyan sediments in the Spiti Basin stretch from Pir Panjal in the south to the Zanskar Range in the north. The Tethyan sediments liewithin theHigher Himalayan Physiographic Zone. Since such huge thicknesses of sediments are deposited in this area, it is anticipated by the geologiststhat favourableconditions might have prevailed for the generation and accumulation of hydrocarbon in the Tethyan sediments. It has been continuous endeavour of ONGC to explore and enhance hydrocarbon reserves from all Indian sedimentary basins including the category IV and frontier basins. Seismic data acquisition and geological modelling havebeen carried out for Lesser Himalayas and even parametric, structural, or wild cat wells havebeen drilled and one such well isunder drilling at Sundernagar. TheTethyan part being inaccessible has not been subjected to detailed geological modelling.

Mesozoic sequences from Kibber Gate Tashegang and LidangDomal traverses havebeen subjected to sedimentological, Palaeontological, Palynological and sourcerock investigationsto reconstruct microfacies, biochronostratigraphy, depositional environment, and organic matter maturation. Thepetrographic study of the Mesozoic Tethyan sediments exposed along the selected traverses shows occurrence of Kioto Limestone, Spiti Shale, Giumal Sandstone, Tashegang Limestone and Chikkim Limestoneformations. The Kioto Limestone is highly sparitised and has poor porosity. The Giumal Sandstone consists of glauconitic sands which are well indurated and have very poor intergranular porosity. The porosity is further reduced by calcite cementation. Similarly, the Tashegang Limestone is also highly sparitised and has poor porosity. Spiti shale is dark grey, black, carbonaceous, occasionally oxidised in nature.
Brachiopod fauna supportive of Lower Carboniferous age has been recorded from Lipak Formation and Ordovician Silurian fauna from TakcheFormation. Cephalopods supportive ofOxfordian - Callovian agehave been recovered from Spiti Shale. Lilang Group has yielded rare Cephalopods of Triassic - Jurassic age. On the basis of FAD of Riguadella filamentosa and Egmontodinium torynum Late Bathonian to LateTithonian age has been suggested to Spiti Formation. On the basis of FAD ofE. anctumand Batioladinium micropodum, LateTithonian to Early Valanginian age has been suggested to Tashegang Formation. On the basis of FAD of B. micropodum the base of Giumal Formation is dated as EarlyValanginian. Theabsolute pollen frequency (APF) value of the palynofloral assemblage from Spiti Formation suggests inner neritic to marginal marine environment of deposition, whilepalynoflorafrom Tashegang Formation indicate marginal marineto lagoonal environmentand Giumal Formation was laid under marginal marineconditions. TheOrganic matter recorded from the studied samples shows Humic-Wood $(\mathrm{H}-\mathrm{W})$ to Humic-Sapropelic-Wood (HS-W) to Humic-SapropelicCharcoal (HS-C) facies.

Theorganic matter studieshaveindicated TAl valuefrom 3 to 3.5 which is suggestive of thermally matured sediments. In general geochemical studies on all the samples have indicated poor hydrocarbon generation potential with verylow TOC except for carbonaceous shales having indicated $>1 \%$ TOC. S2 is very low in many organic rich samples probably due to weathering affects. So an entirely different picture can be anticipated in the subsurface. T max data is not reliable as S2 is low hence no maturity estimate could be made. 